\title{
Feeding behaviour during brooding in the oyster Ostrea chilensis: gut retention time in adults and larvae and potential use of larval faeces by adults
}

\author{
O. R. Chaparro ${ }^{1, *}$, C. J. Soto ${ }^{1}$, R. J. Thompson ${ }^{2}$, I. I. Concha ${ }^{3}$ \\ ${ }^{1}$ Instituto de Biología Marina 'Dr. Jurgen Winter', Universidad Austral de Chile, Casilla 567, Valdivia, Chile \\ ${ }^{2}$ Ocean Sciences Centre, Memorial University of Newfoundland, St. John's, Newfoundland, A1C 5S7, Canada \\ ${ }^{3}$ Instituto de Bioquímica, Universidad Austral de Chile, Casilla 567, Valdivia, Chile
}

\begin{abstract}
The brooded larva of Ostrea chilensis is not an obligate lecithotroph, as has often been supposed, because it removes particles from the mantle cavity of the parent oyster. The ingestion of exogenous particles by the larva becomes apparent when the shell length of the veliger is approximately $290 \mu \mathrm{m}$, the same stage at which the velar ciliature is also visible for the first time. Experiments using red plastic marker particles showed that gut retention time in brooding oysters was significantly greater (10 to $11 \mathrm{~h}$ ) than in non-brooding oysters $(8 \mathrm{~h})$, providing a mechanism for more efficient use of the ingested food. Although there was no significant difference in gut retention time between oysters brooding early and late larval stages, the late brooders eliminated most of the faeces earlier than the early brooders. Experiments using ${ }^{14} \mathrm{C}$-labelled algae demonstrated a shorter gut retention time in the larva $(6 \mathrm{~h})$ than in the non-brooding adult $(10 \mathrm{~h})$. Faeces from larvae contained relatively more chlorophyll $a$ and less phaeopigment than faeces from brooding adults. The data suggest that the digestive system of the larva is much less efficient than that of the adult. Following the introduction of larvae previously fed ${ }^{14} \mathrm{C}$-labelled algae into the pallial cavity of the brooding parent, the radiolabel was detected in the faeces of the adult, suggesting that the parent may ingest faeces produced by the larvae. The increase in gut retention time by the adult during the brooding period and the ingestion of larval faeces compensate for the high energy costs associated with the brooding process.
\end{abstract}

KEY WORDS: Chilean oyster $\cdot$ Gut retention time $\cdot$ Larva $\cdot$ Brooding $\cdot$ Digestion $\cdot$ Chloropigments Resale or republication not permitted without written consent of the publisher

\section{INTRODUCTION}

The reproductive strategy is one of the most characteristic properties of any living organism, impacting on its energy budget to a degree which depends on the mode of reproduction. In the case of brooding species, such as Ostrea chilensis (= Tiostrea chilensis, Buroker et al. 1983; Ostrea (Eostrea) chilensis, Harry 1985; Ostrea puelchana, Carriker et al. 1995), the relationship between the brooding adult and the brooded

*E-mail: ochaparr@mercurio.uach.cl embryos or larvae is often influenced by the feeding processes of the larvae or physical interference by larvae with the pallial structures of the adult (Solís 1967, Winter et al. 1983, Chaparro \& Thompson 1998). The energy cost of the brooding process to the adult oyster can be resolved into 2 main components: direct expenditure resulting from structural and functional changes in the adult, such as gill modifications, ventilation processes, and cleaning and manipulation of larvae (Menge 1974, 1975, Silverman et al. 1985, 1987); and indirect expenditure associated with physical interference by the brooded larvae which reduces the efficiency of processes such as ventilation (Purchon 1977). 
Thus Tankersley (1992) demonstrated that the presence of glochidia in the brooding chamber of Anodonta cataracta significantly influenced acquisition, retention and transport of food particles in the adult, and Winter et al. (1983) considered that the feeding activity of brooding adult oysters $O$. chilensis could be modulated by physical interference by the larvae. Furthermore, the shorter the period of pelagic development, the greater the energy invested per larva (Gallardo 1989), although it does not necessarily follow that shortening or eliminating the larval phase (direct development) is always the more expensive strategy in terms of costs per juvenile produced (Grahame 1977, Todd 1979), since a large parental investment would provide the larva with a better chance of survival. Since it is a brooding species with a brief pelagic phase, O. chilensis should incur all these energy costs of reproduction (direct, indirect and gamete investment) while pursuing a physiological strategy to minimise them (Williams 1966, Schaffer 1974).

In Ostrea chilensis the brooding period is $\sim 8 \mathrm{wk}$ (Toro \& Chaparro 1990). The larvae are maintained in the infrabranchial chamber, where they move freely and concentrate around the labial palps of the adult (Chaparro et al. 1993). This lengthy period of larval development in the pallial cavity is not obligatory lecithotrophy as previously supposed (DiSalvo et al. 1983, Gallardo 1989), since the larva acquires, at some point in its development, the ability to entrain and ingest exogenous food particles that enter the pallial cavity in ventilation currents produced by the adult (Chaparro et al. 1993). Feeding larvae presumably release their faeces inside the pallial cavity of the adult. The larval faeces may have some nutritional value to the adult, because if it does not eliminate them as pseudofaeces, it may ingest them. This would be particularly significant if the digestive system of the larva were not very efficient.

Clearance rate and absorption efficiency are examples of physiological processes that are essential components of food acquisition and utilisation, and which respond to food availability. An increase in absorption efficiency, for example during periods of reduced food intake (Thompson \& Bayne 1972, Bayne \& Newell 1983, Newell \& Jordan 1983), is often associated with an increase in gut retention time, as demonstrated in Choromytilus meridionalis, Perna perna and Aulacomya ater by Bayne et al. (1984). One may therefore hypothesise that brooding adults of Ostrea chilensis can regulate gut retention time in response to the decrease in food intake associated with the reduction in clearance rate observed during the brooding period (Chaparro \& Thompson 1998), and that the direct result will be a loss of body weight, as recorded by Solís (1967) and Winter et al. (1983). In the freshwater bivalve Pyganodon cataracta, Tankersley \& Dimock (1993) also recorded a reduction in clearance rate associated with the presence of larvae in the pallial cavity of the brooding adult.

It has been demonstrated that adult oysters Ostrea chilensis experience physiological stress during the period of larval incubation (Chaparro \& Thompson 1998), and that the larvae are able to utilise exogenous food (Chaparro et at. 1993). In this paper we test the hypothesis that the larval faeces released inside the pallial cavity of the adult represent a source of nutrition for the adult. We therefore determined gut retention times in brooders and in non-brooders, and we examined the possibility that the larval faeces are ingested by the brooding adult. Another means for determining the effectiveness of the digestive process in bivalves is to examine the modulation of chloropigments, especially chlorophyll a (chl a), which occurs when food material passes through the gut (Vernet \& Lorenzen 1987, Strom 1993), either by enzymatic action, separating the phytol groups from the rest of the chl molecule, or by acidification, which removes the magnesium atom (Brown et al. 1977). We determined the phytopigments in larval and adult faeces qualitatively and quantitatively in order to compare the digestive processes of the 2 stages.

\section{MATERIALS AND METHODS}

Location. The research was carried out on oysters Ostrea chilensis from a natural population in the estuary of the Quempillén river $\left(41^{\circ} 52^{\prime} 42^{\prime \prime} \mathrm{S}_{;} 73^{\circ} 47^{\prime}\right.$ $05^{\prime \prime} \mathrm{W}$ ) on the eastern side of the Pudeto river, in Chiloé, southern Chile. The monthly mean water temperature in this estuary fluctuates between 8.8 and $18.9^{\circ} \mathrm{C}$, and the mean salinity between 29.9 and $13.0 \mathrm{psu}$, for winter and summer respectively (Toro \& Winter 1983).

Experimental animals. Adults: A sample of 300 sexually mature oysters, between 50 and $60 \mathrm{~mm}$ shell length, was taken in September 1993, 1 mo before the beginning of the brooding period. To facilitate subsequent sampling of larvae, a hole $\sim 2 \mathrm{~mm}$ in diameter was drilled in the left valve of each oyster, in the anterior region of the pallial cavity. The hole was immediately plugged with a piece of parafilm and the oysters were returned to the estuary, where they were maintained on a long-line for several weeks. A second sample of oysters (shell lengths between 50 and $60 \mathrm{~mm}$ ) was collected $2 \mathrm{~d}$ before the experiments and held in the laboratory in filtered seawater $(1 \mu \mathrm{m})$ at a temperature of $17^{\circ} \mathrm{C}$, a salinity of $27 \mathrm{psu}$ and with a diet of 30000 cells ml ${ }^{-1}$ Isochrysis galbana. Air was continuously bubbled through the water. The size range of 
oysters used was optimal for obtaining a high proportion of brooders.

Larvae: Larvae of Ostrea chilensis were obtained by opening brooding females immediately after collection from the estuary and gently rinsing the larvae into a beaker with a jet of filtered seawater. Larvae in several development stages were used, depending on experimental requirements, but always immediately after their separation from the adult.

Stage at which the larva begins to feed. The first ingestion of exogenous particles was established by examining the guts of larvae at different developmental stages from the beginning of brooding to the pediveliger stage. Each batch of larvae from a single oyster was maintained in a dish with $50 \mathrm{ml}$ filtered seawater, under the experimental conditions previously described. A concentrated suspension of non-toxic red plastic particles (2 to $10 \mu \mathrm{m}$ diameter; Chaparro et al. 1993) was added to each dish. After 2 h, a sample of larvae from each batch was fixed with $5 \%$ formaldehyde. The larvae were examined under a stereomicroscope and the percentage of larvae with red particles in the stomach enumerated. This task was facilitated by the transparency of the larval shell and the red colour of the particles.

After the stage at which the larva of Ostrea chilensis begins to feed actively was established, each brooding female was assigned to 1 of 2 groups, depending on the development stage of a sample of larvae aspirated through the hole previously made in the shell. The first group contained those oysters incubating larvae that had yet to reach the stage at which feeding begins. This group was termed the early brooders. The second group, termed the late brooders, contained only oysters incubating larvae that had attained the feeding stage.

Gut retention time in brooding and in non-brooding adult oysters in estuary water under ambient conditions. Gut retention time was measured in 3 groups of oysters (3 replicates per group): (1) early brooders, incubating non-feeding larvae, (2) late brooders, incubating feeding larvae, and (3) non-brooders. Each oyster was maintained in a separate chamber with a constant flow of water directly from the estuary, i.e. water whose characteristics fluctuated according to the tidal cycle. At the beginning of the experiment, during high tide, oysters were placed for $30 \mathrm{~min}$ in a suspension of red plastic particles (2 to $10 \mu \mathrm{m}$ diameter) in filtered seawater, after which the oysters were returned to their individual chambers. All faeces produced by an individual oyster were collected hourly and examined under a stereomicroscope in order to estimate the proportion of red coloration in the faeces. Those cases for which the faeces appeared completely red were assigned a value of $100 \%$, whereas those cases in which no red particles were seen were assigned a value of
$0 \%$. For intermediate cases, values were assigned based on an estimate of the proportion of coloration in the faeces. In order to prevent bias, the intermediate samples were counted in a haphazard sequence, and the observer did not know from which oyster any given sample came, nor the time the sample was taken. A total of 27 oysters was examined in this way. Gut retention time was defined as the time (post-peak) at which red particles represented $20 \%$ of the sample.

Gut retention time in non-brooding adult oysters fed with microalgae. For the estimation of gut retention time in adult oysters fed with microalgae, a pulse of radiolabelled algae was used as a marker and the radiolabel content of the faeces determined at hourly intervals.

Radiolabelling of microalgae: $20 \mathrm{ml}$ of a solution of $0.1 \mu \mathrm{Ci} \mathrm{NaH}{ }^{14} \mathrm{CO}_{3} \mathrm{ml}^{-1}$ was added to $100 \mathrm{ml}$ of a culture of Isochrysis galbana (concentration 5-6 $\times 10^{6}$ cells $\mathrm{ml}^{-1}$ ). The culture was maintained for $48 \mathrm{~h}$ at $17^{\circ} \mathrm{C}$, with constant light and air bubbling, to allow incorporation of the radiolabel into the cells (Hawkins \& Bayne 1984).

Feeding of adult oysters with radiolabelled microalgae and collection of faeces: 16 adult non-brooding Ostrea chilensis were maintained in 21 filtered seawater, to which was added $30 \mathrm{ml}$ radiolabelled Isochrysis galbana culture $\left(\sim 1 \times 10^{6} \mathrm{cpm}{ }^{14} \mathrm{C}\right)$. The oysters were exposed to the labelled cells for $30 \mathrm{~min}$ at a concentration of 60000 cells ml$^{-1}$. The valves were then washed thoroughly with filtered seawater and the oysters immediately placed in PVC tubes (height: $20 \mathrm{~cm}$, diameter: $7 \mathrm{~cm}$ ), 1 oyster per tube. The base of each tube was formed by a piece of Nitex screen $(50 \mu \mathrm{m}$ mesh), which retained all the faeces produced. The tubes were positioned vertically in a plastic tank containing $30 \mathrm{l}$ filtered seawater $\left(17^{\circ} \mathrm{C}, 27 \mathrm{psu}\right)$ to which $I$. galbana had been added $\left(30000\right.$ cells ml $\left.^{-1}\right)$. All faeces produced were aspirated from the screens with Pasteur pipettes hourly over a period of $24 \mathrm{~h}$ and placed on Whatman GF/C glass fibre filters (25 $\mathrm{mm}$ diameter). Each sample represented the total faecal production by an individual oyster in $1 \mathrm{~h}$. Samples were kept separate and analysed individually.

Processing of samples: Filters were dried at $60^{\circ} \mathrm{C}$ for $24 \mathrm{~h}$, then treated with $1 \mathrm{ml}(0.5 \mathrm{M})$ SOLVABLE (New England Nuclear, Boston, MA) for $12 \mathrm{~h}$ at $50^{\circ} \mathrm{C}$ to dissolve the organic matter. The vials were cooled and $10 \mathrm{ml}$ AQUASOL (New England Nuclear) added to each one. Activity of ${ }^{14} \mathrm{C}$ was determined with a betacounter (Canberra Packard), using an external standard for quench correction, and the values were expressed in counts per minute (cpm), after correction for background radiation. Values for each sampling period were expressed as percentages of the maximum (peak) observed. Gut retention time was defined as the 
time at which the counts had decreased to $10 \%$ of the peak value.

Gut retention time in larvae fed with microalgae. The procedure followed was similar to that followed for adult oysters i.e. a pulse of ${ }^{14} \mathrm{C}$-labelled food (Isochrysis galbana) was fed to the oyster and the radiolabel determined in the faeces as a function of time.

Determination of period required for pulsing larvae with radiolabelled microalgae: A preliminary experiment was undertaken to determine an appropriate length of time for a pulse of radiolabelled food to be given to the larvae. Twelve batches of pediveliger larvae, each batch from a separate adult oyster, were used for this purpose. The criteria for selection of the larvae were the presence of the foot and eye spot, and a shell length between 470 and $510 \mu \mathrm{m}$ (Solís 1967). Each batch was placed in a separate container with $20 \mathrm{ml}$ filtered seawater $\left(17^{\circ} \mathrm{C}\right)$ containing a high density of red plastic particles (diameter 2 to $10 \mu \mathrm{m}$ ). The presence or absence of particles in the gut was determined at frequent intervals for $2 \mathrm{~h}$. At each sampling time several larvae of each batch were removed, rinsed with filtered seawater and observed under a stereomicroscope. The earliest time at which the gut was full of marker particles was identified (45 min).

Feeding of pediveliger larvae with radiolabelled microalgae and collection of faeces: Pediveligers were obtained by opening brooding females taken directly from the estuary. Each batch (i.e. larvae from a single parent) was isolated from the others in a separate container with $250 \mathrm{ml}$ filtered seawater $\left(17^{\circ} \mathrm{C}\right.$, $27 \mathrm{psu}$ ), and $30 \mathrm{ml}$ of radiolabelled Isochrysis galbana culture added (activity $\sim 1 \times 10^{6} \mathrm{cpm}$, concentration in experimental container $\sim 4 \times 10^{5}$ cells $\mathrm{ml}^{-1}$ ).

After receiving the pulse of radiolabelled microalgae (45 min), the larvae were concentrated on a Nitex screen (150 $\mu \mathrm{m}$ mesh) and washed copiously with filtered seawater to remove any radiolabel remaining on the surface of the shell. They were then returned to their original containers (temperature $17^{\circ} \mathrm{C}, 27 \mathrm{psu}$, $1 \mu \mathrm{m}$ filtered seawater). The faeces produced by each batch of larvae were collected at hourly intervals in the following way. The larvae were collected on a $150 \mu \mathrm{m}$ Nitex screen, which allowed the larval faeces to pass. The larvae retained on the sieve were washed with filtered seawater to remove any faeces which may have adhered to them. The seawater from the container and the filtered seawater used to wash the larvae were then passed through a glass-fibre filter (GF/C, $25 \mathrm{~mm}$ diameter) under gentle vacuum. Faeces produced by the larvae were retained on the filter. Immediately after each sampling, the larvae were replaced in their containers under the same experimental conditions, which were maintained throughout the experiment. Filters were dried at $60^{\circ} \mathrm{C}$ for $24 \mathrm{~h}$ and stored in a desiccator until processed for counting. Faeces produced by 1 batch of oysters during a $1 \mathrm{~h}$ period comprised a single sample.

Does the adult oyster consume faeces produced by the larvae? A group of 16 brooding oysters (shell length 50 to $60 \mathrm{~mm}$ ) with larvae at an advanced stage of development (pediveligers of 470 to $510 \mu \mathrm{m}$ shell length) was selected from those that had been taken from the estuary several weeks before the beginning of the reproductive period. In order to identify the larval stage, a sample of larvae from each oyster was taken by introducing the tip of a Pasteur pipette through the hole previously drilled in the left valve. The larvae were immediately examined under a microscope and the stage identified according to the criteria of Solís (1967). The 16 oysters selected for use in the experiment were set aside and returned to the estuary. The hole in the shell was replugged with parafilm to prevent the loss of larvae. The selected brooders were moved from the estuary to the laboratory $2 \mathrm{~d}$ before the beginning of the experiment, and were then maintained in seawater at $17^{\circ} \mathrm{C}$ and $27 \mathrm{psu}$, and fed with Isochrysis galbana (30000 cells ml-1).

Several hours before the experiment was to begin, 8 batches of pediveligers, each from a different parent, were collected from the selected group of brooding oysters by opening each female and gently rinsing the entire brood of larvae into a beaker with a jet of filtered seawater. These larvae were fed with radiolabelled Isochrysis galbana, as previously described. A sample $(0.5 \mathrm{ml})$ of the pediveliger suspension was obtained from each of 8 more oysters from the selected group by withdrawing samples with a Pasteur pipette through the hole drilled in the shell. These larvae were replaced by injecting radiolabelled larvae from a single donor oyster into the pallial cavity of the recipient (approximately the same number of larvae as had earlier been removed). Since the larvae incubated by any given oyster are at the same developmental stage at any given time, and since there is variation between parent oysters in the larval stage on any given date, each pair of donor and recipient adult oysters was matched in terms of the shell length of larvae used, i.e. recipients were injected with larvae of approximately the same size as those which they were incubating. The 8 recipient oysters were replaced in separate containers, and the accumulated faeces collected $24 \mathrm{~h}$ later. Faeces from individual oysters were kept separate. Faeces were sampled and processed as previously described.

Faecal chloropigments. Collection of faeces: Thirteen brooding oysters (50 to $60 \mathrm{~mm}$ shell length) were taken from the estuary and the pediveligers carefully removed from the pallial cavity with jets of filtered seawater $(0.47 \mu \mathrm{m})$. Each batch of larvae $(1$ batch $=$ yield from 1 female) was processed separately from the 
others. The larvae were retained on a Nitex screen (250 $\mu \mathrm{m}$ mesh), washed with filtered seawater, held for $3 \mathrm{~h}$ in $100 \mathrm{ml}$ filtered seawater to allow production of faeces, then retained again on the same screen. The water containing the faeces from the larvae passed through the screen. The faeces were then collected under gentle vacuum on glass fibre filters (Millipore AP40 047), 1 filter per batch, and the filters frozen immediately in liquid nitrogen. Filters were stored in darkness at $-20^{\circ} \mathrm{C}$ to await analysis.

At the same time, 12 non-brooding oysters were moved from the estuary to the laboratory. Each oyster was placed in a separate container with $10 \mathrm{l}$ filtered seawater $(50 \mu \mathrm{m})$ taken directly from the estuary at high tide. The oysters were held for 5 to $6 \mathrm{~h}$ and faeces produced by each oyster then collected, i.e. 1 sample from each oyster. Only material in the form of a ribbon close to the exhalant siphon was removed, ensuring that the sample contained only true faeces produced by the oyster. The faeces were concentrated and stored as described above for larval faeces.

Sampling of seston: Water samples (200 to $250 \mathrm{ml}$ ) were taken from the same depth as the pearl nets in which the oysters were held in the estuary $(50 \mathrm{~cm}$ from the bottom). Samples were filtered and the filters containing seston stored as described above for faecal samples.

Extraction of chloropigments: Filters containing seston and faeces were immersed in $90 \%$ acetone in darkness at $0^{\circ} \mathrm{C}$ for approximately $24 \mathrm{~h}$ in order to extract chloropigments (Bowles et al. 1985). The samples were then sonicated for $8 \mathrm{~min}$ and later centrifuged (12000 $\mathrm{RCF}$ ) for $\sim 3 \mathrm{~min}$ in order to remove glass fibres and other debris. The supernatant was removed with a Pasteur pipette, the pellet washed with $90 \%$ acetone, and the supernatant and washings made up to $2 \mathrm{ml}$ with $90 \%$ acetone. $500 \mu \mathrm{l}$ of the extract was transferred to a $1.5 \mathrm{ml}$ propylene tube and stored in darkness at $-70^{\circ} \mathrm{C}$ for subsequent separation of chloropigments by HPLC. The entire process was carried out in near-darkness.

Fluorometry: Chloropigments in the extract were quantified with a fluorometer (Turner Designs Model 10), with excitation and emission wavelengths of $430 \mathrm{~nm}$ and $670 \mathrm{~nm}$ respectively, before and after acidification with 3 drops $1 \mathrm{M} \mathrm{HCl}$ (Riemann 1978). Chl a and total phaeopigments were calculated (Strickland \& Parsons 1972) and expressed as ng ml ${ }^{-1}$ extract.

Separation of chloropigments: $\mathrm{Chl} a, b$, and $c$, together with the phaeopigments, were separated and quantified with a Beckman HPLC (Mantoura \& Llewellyn 1983, Bidigare et al. 1985). The HPLC was fitted with a $4.6 \times 250 \mathrm{~mm}$ reverse phase ODS-C18 column with a pore size of $5 \mu \mathrm{m}$, a model 126 quaternary pump, and a Gilson model 121 fluorescence detector with an excitation filter of wavelength 345 to $510 \mathrm{~nm}$, and emission filter of 610 to $650 \mathrm{~nm}$. Immediately prior to injection, $150 \mu \mathrm{l} 1 \mathrm{M}$ ammonium acetate was added to the $500 \mu \mathrm{l}$ sample in order to improve the resolution of the peaks. A $100 \mu \mathrm{l}$ aliquot of the sample was injected into the HPLC at a solvent flow rate of $1.55 \mathrm{ml}$ $\mathrm{min}^{-1}$. Chl $a$ and $b$ were purchased from Sigma Chemical Co. All other standards were prepared from algal cultures (Wright et al. 1991). The concentration of each pigment was determined from the area of the appropriate peak, integrated using the Beckman Gold software supplied with the HPLC. The detection limit for chl a was $0.2 \mathrm{ng} \mathrm{ml}^{-1}$ (reproducibility $\pm 0.05 \mathrm{ng} \mathrm{ml}^{-1}$ ).

Statistical analysis. Values expressed in terms of percentages were transformed using the arcsine function before statistical analysis (Sokal \& Rohlf 1981). The non-parametric Friedman and Kruskal-Wallis procedures, as well as parametric analysis of variance, were used to test for differences between treatments.

\section{RESULTS}

\section{Stage at which the larva begins to feed}

Red particles were not seen in the stomach until the shell length of the larva reached between 290 and $300 \mu \mathrm{m}$ (Fig. 1), corresponding to the early veliger stage, when the velum begins to develop cilia (Solís 1967).

\section{Gut retention time in brooding and in non-brooding adult oysters in estuary water under ambient conditions}

In each of the 3 groups (early brooders, late brooders and non-brooders), there was no significant difference

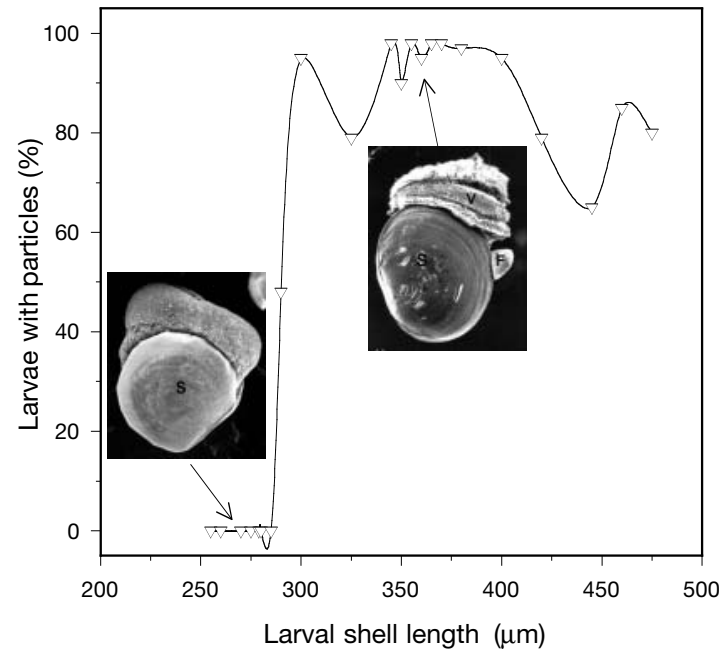

Fig. 1. Ostrea chilensis. Percentage of larvae with particles in gut ( $\mathrm{n}=50$ for each point). $\mathrm{F}=$ foot, $\mathrm{S}=$ shell, $\mathrm{V}=$ velum 


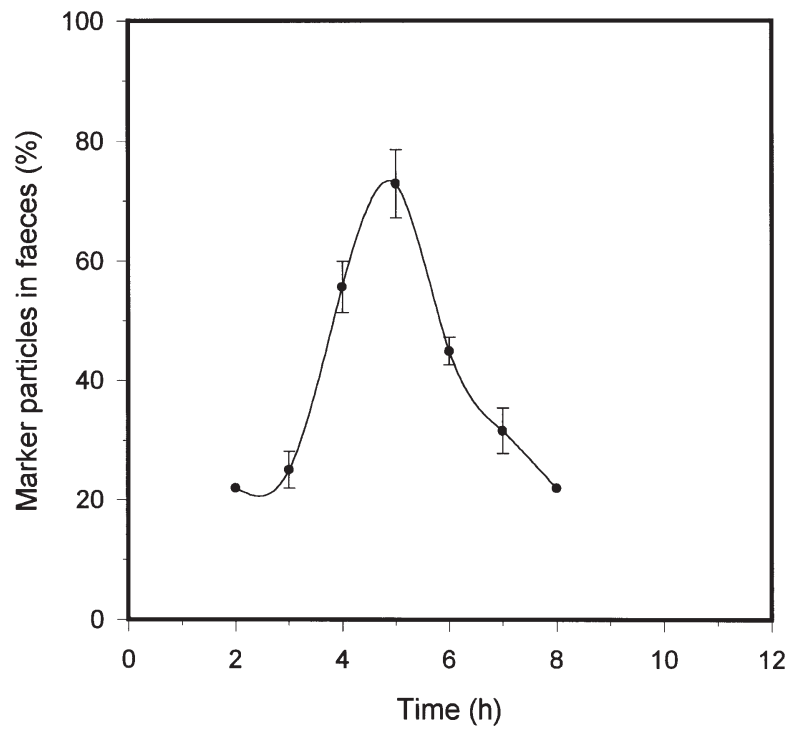

Fig. 2. Ostrea chilensis. Gut retention time in non-brooding oysters (red particle marker). Values represent percentage particle content of faeces (completely red sample $=100 \%$ ). Mean \pm SE

among individual oysters in marker particles as a percentage of faecal matter at any given sampling time (Friedman test, $\mathrm{p}>0.05$ ). In non-brooding oysters, marker particles were first apparent in the faeces $2 \mathrm{~h}$ after the feeding pulse, peaked at $5 \mathrm{~h}$ and were almost completely eliminated after $8 \mathrm{~h}$ (gut retention time) (Fig. 2). For early brooders (Fig. 3) the corresponding initial, peak and got retention times were 3,8 and $11 \mathrm{~h}$,

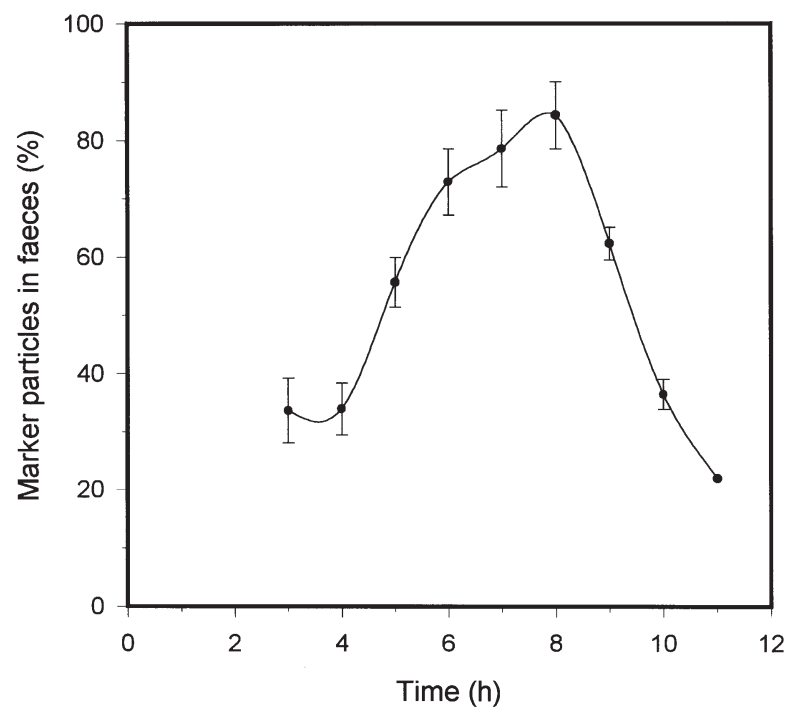

Fig. 3. Ostrea chilensis. Gut retention time in early brooding oysters (red particle marker). Values represent percentage particle content of faeces (completely red sample $=100 \%$ ). Mean \pm SE and for late brooders (Fig. 4) 3,5 and $10 \mathrm{~h}$ respectively. The gut retention time of the non-brooding oysters was significantly shorter than that of the early or late brooders (Kruskal-Wallis test, $\mathrm{p}<0.05$ ), but there was no significant difference between gut retention times for early and late brooders. However, the peak in faeces elimination occurred significantly earlier in late brooders than in early brooders (Kruskal-Wallis test, $p$ $<0.05)$, although in the late brooders there was evidence of prolonged retention of material in the gut $8 \mathrm{~h}$ after the feeding pulse (Fig. 4), corresponding to the peak at $8 \mathrm{~h}$ observed for the early brooders (Fig. 3).

\section{Gut retention time in larvae and non-brooding adult oysters fed with microalgae}

The maximum release of radiolabel in the faeces of non-brooding adult oysters occurred $4 \mathrm{~h}$ after the oysters were fed radiolabelled Isochrysis galbana (Fig. 5). A second peak was observed at 6 to $7 \mathrm{~h}$, and the gut retention time was $10 \mathrm{~h}$. The first peak probably represented 'intestinal' faeces, i.e. material that had bypassed the digestive gland; the second peak probably represented 'glandular' faeces, i.e. material that had passed through the digestive gland (Van Weel 1961, Thompson \& Bayne 1972, Calow 1975, Widdows et al. 1979). There was also some separation of the 2 peaks in the data for late brooders in the red marker particle experiment (Fig. 4). In the larvae (Fig. 6), radiolabelled faeces were produced much earlier $(1 \mathrm{~h})$ than in the adults $(2 \mathrm{~h})$, and gut retention time was sig-

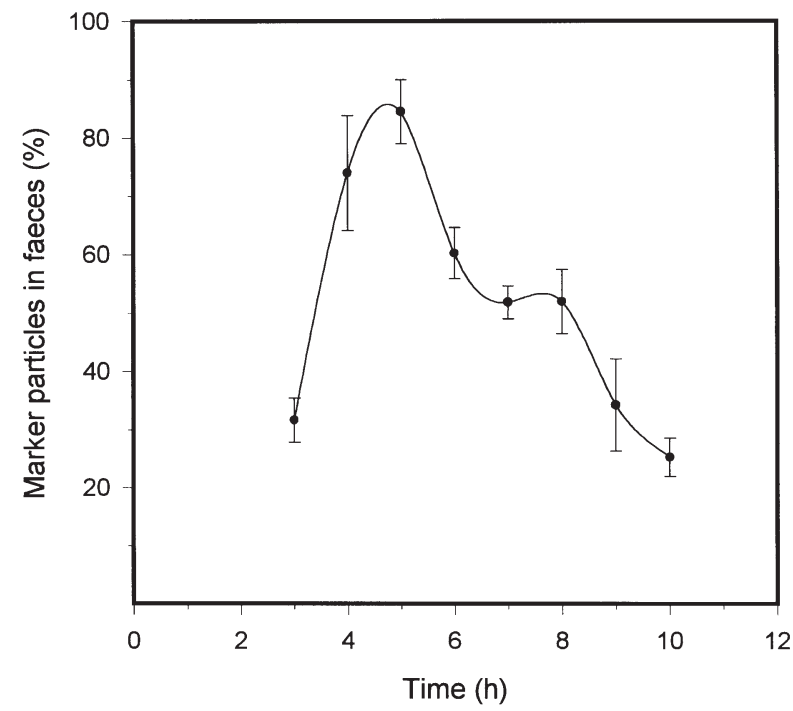

Fig. 4. Ostrea chilensis. Gut retention time in late brooding oysters (red particle marker). Values represent percentage particle content of faeces (completely red sample $=100 \%$ ). Mean \pm SE 
nificantly shorter (6 hi Kruskal-Wallis test, $\mathrm{p}<0.05)$. The separation into 2 peaks was not observed in faeces from the larva. There were no significant differences in ${ }^{14} \mathrm{C}$ counts in the faeces among individual adults or larvae at any given sampling time (Friedman test, $\mathrm{p}>0.05)$.

\section{Does the adult oyster consume faeces produced by the larvae?}

Levels of ${ }^{14} \mathrm{C}$ were low in the faeces of oysters incubating larvae fed with radiolabelled algae (mean $78.5 \mathrm{cpm}, \mathrm{SE} 10.1)$, but significantly higher $(\mathrm{p}<0.05)$ than background values (mean $25.4 \mathrm{cpm}, \mathrm{SE}$ 0.376), suggesting that the adults consumed faecal material egested by the larvae. Since the larvae (470 to $510 \mu \mathrm{m}$ diameter) were much larger than the food particles normally ingested, the likelihood of ingestion of larvae by the brooding adult was very small, and no shell fragments were observed in the faeces of the adult.

\section{Faecal chloropigments}

Chl a represented $19 \%$ of total chloropigments in the seston (Table 1), but only 10.7 and $5.1 \%$ in faeces from the larva and adult respectively. This is equivalent to 56 and $26.8 \% \mathrm{chl}$ a relative to seston (100\%), indicating that the adult oyster absorbed or degraded proportionately more chl a than the larva (ANOVA; $\mathrm{p}<0.05)$.

Faeces from adult oysters showed a much greater degree of breakdown of chlorophyll than did faeces from larvae (Figs $7 \& 8$; for identification of peaks see Table 2). Thus chl $a$ and $b$ represented a greater proportion of total chloropigments in faeces from the larva, whereas faeces from the adult contained less chl $a$ and $b$, but much more phaeophytin $a, a 4$, and $c_{\text {, }}$ as well as phaeophorbides a1 and a5 and pyrophaeophorbide $a$. In faeces from the adult, phaeophytin a4 was the most abundant chloropigment, accounting for $8.5 \%$ of the total, whereas in faeces from the larva chl a was the most abundant, representing $10.7 \%$ of the total.

\section{DISCUSSION}

\section{Stage at which the larva begins to feed}

Observations made with the endoscope by Chaparro et al. (1993) showed

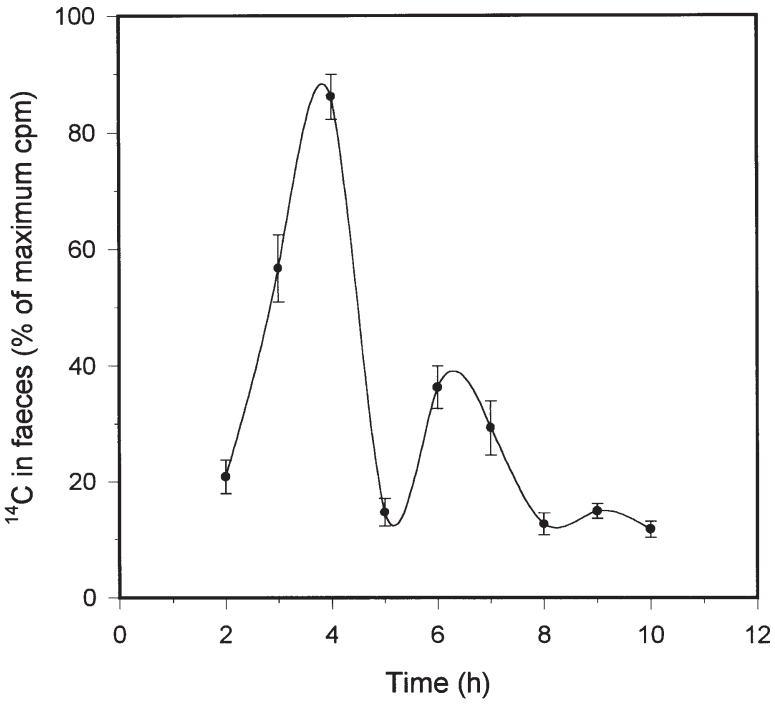

Fig. 5. Ostrea chilensis. Gut retention time in non-brooding oysters $\left({ }^{14} \mathrm{C}\right.$ marker). Values represent counts as \% of maximum count recorded. Mean $\pm \mathrm{SE}$

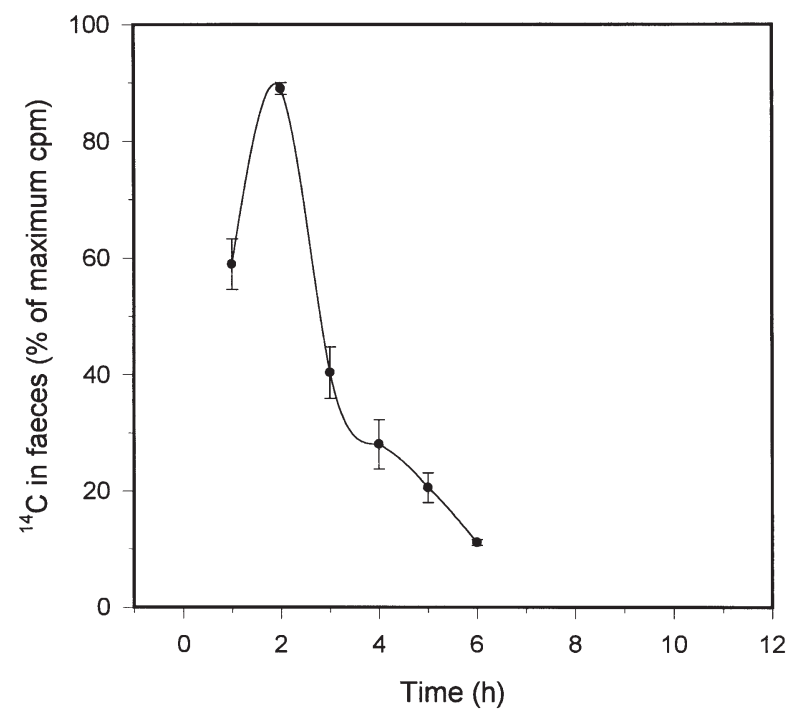

Fig. 6. Ostrea chilensis. Gut retention time in larvae $\left({ }^{14} \mathrm{C}\right.$ marker). Values represent counts as \% of maximum count recorded. Mean $\pm \mathrm{SE}$

Table 1. Chl a and total chloropigments in seston and in faeces of larvae and adult non-brooding oysters. Mean \pm SD. Chl a (\% total) normalised with reference to seston $(100 \%)$

\begin{tabular}{|lcccc|}
\hline Sample & $\begin{array}{c}\mathrm{Chl} a \\
\left(\mathrm{ng} \mathrm{m}^{-1} \text { extract) }\right. \\
\text { (ng ml }{ }^{-1} \text { extract) }\end{array}$ & $\begin{array}{c}\text { Total chloro- } \\
\text { pigments }\end{array}$ & $\begin{array}{c}\text { Chl } a \\
\text { (\% total) }\end{array}$ & $\begin{array}{c}\text { Chl } a \\
(\% \text { total })\end{array}$ \\
\hline Seston & $65.8 \pm 3.5$ & $344 \pm 19$ & $19.0 \pm 0.08$ & 100 \\
Larval faeces & $47.3 \pm 16$ & $442 \pm 131$ & $10.7 \pm 0.72$ & 56.0 \\
Adult faeces & $127 \pm 25$ & $2472 \pm 508$ & $5.1 \pm 1.32$ & 26.8 \\
\hline
\end{tabular}


Table 2. Key for identifying chloropigment peaks in HPLC chromatograms (Figs 7 \& 8)

\begin{tabular}{|ll|}
\hline Peak & Chloropigment \\
\hline 1 & Chlorophyllide $a$ \\
2 & Chlorophyll $c$ \\
3 & Phaeophorbide $a 1$ \\
4 & Phaeophytin $c$ \\
5 & Pyrophaeophorbide $a$ \\
6 & Phaeophytin $a 4$ \\
7 & Phaeophorbide $a 5$ \\
8 & Phaeophorbide $a 6$ \\
9 & Chlorophyll $b$ \\
10 & Chlorophyll $a$ allomers \\
11 & Chlorophyll $a$ \\
12 & Chlorophyll $a$ epimers \\
13 & Phaeophytin $b$ \\
14 & Phaeophytin $b$ isomer \\
15 & Phaeophytin $a$ \\
16 & Phaeophytin $a$ isomer \\
17 & Pyrophaeophytin $a$ \\
& \\
\hline
\end{tabular}

that the larva of Ostrea chilensis is not an obligate lecithotroph during the brooding period, as had previously been supposed (DiSalvo et al. 1983, Gallardo 1989). During the brooding phase the larva acquires the ability to ingest exogenous food entering the mantle cavity of the adult in the inhalent current. In the present study, the shell length of the larva at first feeding was between 290 and $300 \mu \mathrm{m}$, the stage at which the velum appears (Chaparro et al. 1999), allowing the larva to feed, like other bivalve veligers (Strathmann 1978). The larval ciliature of $O$. chilensis is primarily

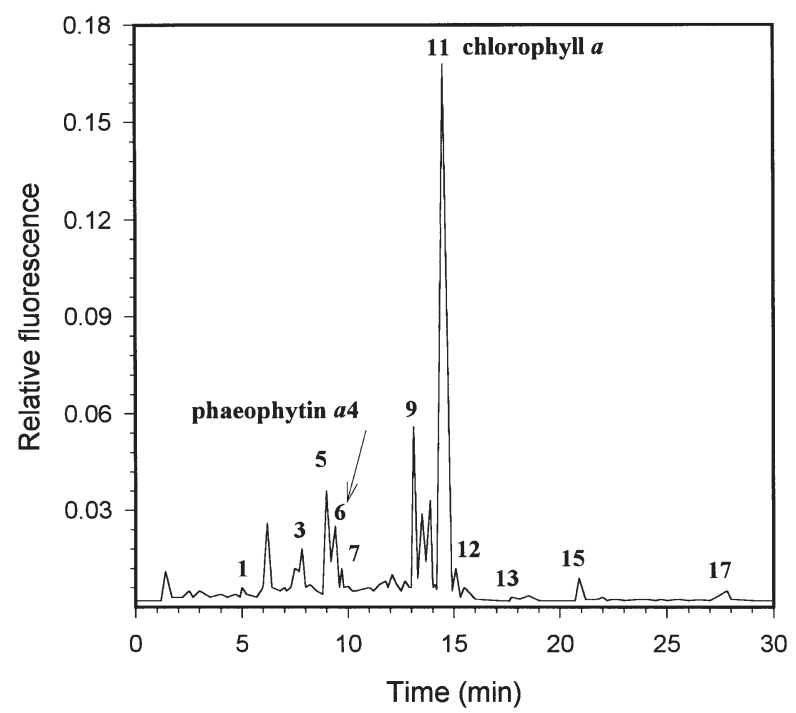

Fig. 7. Ostrea chilensis. HPLC chromatogram of chloropigments in faeces from larvae (see Table 2 for identification of peaks) composed of a preoral ciliary band (prototroch) with long cirri, together with a band of short cilia (adoral cilia) which overlies the food groove. A similar ciliary structure has been identified in the veliger of $O$. edulis (Waller 1981), although in this case there is also a second band of cirri, the postoral cirri. According to Waller (1981), both the preoral and postoral bands may participate in swimming and particle capture. The principal function of the preoral band in $O$. chilensis is probably swimming during the short planktonic phase, but it may also play a role in feeding.

\section{Gut retention time in brooding and in non-brooding oysters under natural conditions}

Control of gut retention time has been demonstrated in Mytilus edulis and Cerastoderma edule (Hawkins et al. 1984, 1990), and a strong positive relationship between absorption efficiency and gut retention time has been recorded in $M$. edulis (Hawkins \& Bayne 1984). Both variables are determined in part by the quality of the food (Taghon 1981), its degree of digestibility (Bricelj et al. 1984) and the amount ingested (Hawkins et al. 1984). An inverse relationship between food concentration and gut retention time has been described in $M$. edulis (Hawkins et al. 1984).

Our data show that brooding oysters (Ostrea chilensis) retain food in the digestive system for longer than non-brooding oysters, allowing more efficient use of the ingested material. The longer gut retention time in brooding oysters may compensate for the costs of

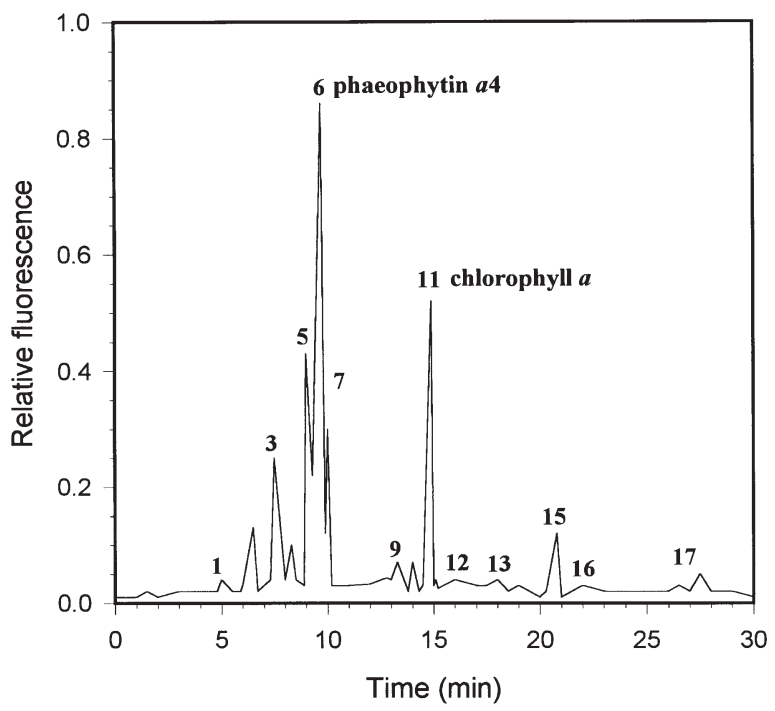

Fig. 8. Ostrea chilensis. HPLC chromatogram of chloropigments in faeces from non-brooding adults (see Table 2 for identification of peaks) 
brooding (Purchon 1977), which may result from physical interference by the larvae or disturbances to the physiological state of the brooder. For example, it has been demonstrated that in Anodonta cataracta the presence of glochidia in the brooding chamber significantly influences the entrainment, retention and transport of food particles (Tankersley 1992). In O. chilensis, the increase in gut retention time in brooding adults may be a response to a reduction in feeding rate (Chaparro \& Thompson 1998), possibly resulting from physical disruption of the particle collection system (Winter et al. 1983). The ingestion rate of the adult is also reduced by the feeding activity of the brooded larvae, since the larvae can intercept food particles entering the pallial cavity. This reduced acquisition of energy by the brooding oysters is reflected in a decrease in meat content observed during the brooding period (Solís 1967, Winter et al. 1983, Chaparro \& Thompson 1998). The increase in gut retention time in brooding oysters is adaptive, since it results in more efficient use of the ingested food, partially compensating for reduced energy intake during brooding.

Although there were no significant differences between early and late brooders in gut retention time as defined here ( $p>0.05$; Figs $3 \& 4)$, the latter egested most of the food earlier than the former $(p<0.025)$, i.e. the peak for ${ }^{14} \mathrm{C}$ counts occurred earlier in the late brooders. These observations are consistent with those of Chaparro \& Thompson (1998), who found that clearance rate is reduced in those oysters incubating early larval stages, probably because at this stage the larvae remain inactive for long periods of time between the gills of the adult oyster, interfering with the circulation of water in the mantle cavity. Thus a reduced clearance rate in early brooders is associated with a later peak in the egestion of the radiolabel. Bayne et al. (1984) recorded a similar response in Mytilus edulis, in which a decrease in clearance rate resulted in an increase in the gut retention time.

\section{Gut retention time in brooded larvae and in non- brooding adult oysters}

Gut retention time in brooded larvae fed with microalgae was $\sim 5 \mathrm{~h}$, most of the radiolabel being egested during the $2 \mathrm{~h}$ immediately following ingestion. To our knowledge this is the first reported measurement of gut retention time in a marine invertebrate larva. The value of $5 \mathrm{~h}$ considerably exceeds the 50 min recorded at $15^{\circ} \mathrm{C}$ by Kiørboe et al. (1982) for the copepod Centropages hamatus, which has a simple, relatively undifferentiated gut. On the other hand, the gut retention time in adult non-brooding oysters in our study was $10 \mathrm{~h}$, a value obtained with the same technique used for the larvae (radiolabelled carbon). These values are close to those recorded for Mytilus edulis (Hawkins et al. 1984, Bayne et al. 1987) and for Choromytilus meridionalis, Aulacomya ater and Perna perna (Bayne et al. 1984) under similar experimental conditions, although comparisons of gut retention time values with those in the literature must be made with caution, since the operating definition of gut retention time is subjective and often varies between studies. Furthermore, different markers have been used by various authors, further confounding the problem. Nevertheless, our values for gut retention time in non-brooding oysters using an inorganic marker (plastic particles, $8 \mathrm{~h}$ ) were similar to those obtained with an organic marker (radiocarbon labelled algae, $10 \mathrm{~h}$ ).

Food passes more rapidly through the gut of the oyster larva than through the gut of the adult, suggesting that digestion may be less efficient and/or less complete in the larva, which has a shorter digestive tract. Although there are some references in the literature to assimilation or absorption efficiencies in bivalve larvae, the values have usually been derived from measurements of the rates of ingestion, metabolism and growth (e.g. Sprung 1984), and we can find no direct comparisons of absorption efficiencies between adult and larval bivalves. The degree of chlorophyll degradation is a good indicator of digestion efficiency in a suspension feeder (Urban et al. 1992), and Penry \& Frost (1990) demonstrated that more rapid transport of material through the digestive system of the copepod Calanus pacificus resulted in less pigment degradation. However, the use of chloropigments to quantify the absorption or assimilation efficiency of carbon or organic material is controversial (Nelson 1989). In our study, the faeces of oyster larvae contained a significantly greater proportion of chl a relative to phaeopigments than did faeces produced by the adults. The main fluorescent products of chl a degradation are chlorophyllides, phaeophytins and phaeophorbides (Yentsch 1967), whose chemical structures have been described by Mantoura \& Llewellyn (1983). Phaeophorbides are associated with a high degree of chlorophyll degradation by herbivores (Madin \& Cetta 1984, Vernet \& Lorenzen 1987), and are more prominent in faeces of adult $O$. chilensis than in faeces from larvae (this study). Furthermore, intermediate degradation products such as phaeophytin a (Brown et al. 1977) were also found in lower proportions in faeces from oyster larvae in our study, phaeophytin a accounting for only $2 \%$ of the total chloropigments, whereas in the adult it occurred in a higher proportion than any other chloropigment, representing $10 \%$ of the total. The shorter gut retention time and apparent lack of separation between glandular and intestinal faeces in the 
larva, together with the greater degree of chlorophyll degradation in faeces from the adult, strongly suggest that the digestive system of the larva is less efficient than that of the adult oyster, and that the digestive gland may be less well developed in the larva.

\section{Does the adult oyster consume faeces produced by the larvae?}

Faeces produced by larvae represent an energy-rich potential food source for the brooding adult oyster, which is subjected to considerable nutritional stress during the brooding period (Chaparro \& Thompson 1998). We have 2 pieces of evidence suggesting that larval faeces can be ingested by the brooding adult oyster; firstly, no pseudofaeces production was observed, indicating that the larval faeces were not ejected from the mantle cavity, and secondly, radiocarbon originating from larvae that had been fed radiolabelled algae was detected in the faeces produced by the adult. The nutritional significance of the larval faeces to the adult is at present unknown.

Acknowledgements. This research was funded by grants to O.R.C. by FONDECYT Chile (Grants 1930364 and 1980984), the International Foundation for Science (IFS-Sweden), and the Dirección de Investigaciones, Universidad Austral de Chile, and by a Research Grant to R.J.T. from NSERC. Financial support was also provided by the Canadian International Development Agency (CIDA). Chloropigment chromatography and radionuclide counting were done by Ms E. Hatfield.

\section{LITERATURE CITED}

Bayne BL, Newell RC (1983) Physiological energetics of marine molluscs. In: Russell-Hunter WD (ed) The Mollusca, Vol 4. Academic Press, London, p 421-434

Bayne BL, Klumpp DW, Clarke KR (1984) Aspects of feeding, including estimates of gut residence time, in three mytilid species (Bivalvia, Mollusca) at two contrasting sites in the Cape Peninsula, South Africa. Oecologia 64:26-33

Bayne BL, Hawkins AJ, Navarro E (1987) Feeding and digestion by the mussel Mytilus edulis (Bivalvia:Mollusca) in mixtures of silt and algal cells at low concentrations. J Exp Mar Biol Ecol 111:1-22

Bidigare RR, Kennicutt MC, Brooks JM (1985) Rapid determination of chlorophylls and their degradation products by high performance liquid chromatography. Limnol Oceanogr 30:432-435

Bowles ND, Paerl HW, Tucker J (1985) Effective solvents and extraction periods employed in phytoplankton carotenoid and chlorophyll determinations. Can J Fish Aquat Sci 42: 1127-1131

Bricelj VM, Bass AE, Lopez GR (1984) Absorption and gut passage time of microalgae in a suspension feeder: an evaluation of the ${ }^{51} \mathrm{Cr}:{ }^{14} \mathrm{C}$ twin tracer technique. Mar Ecol Prog Ser 17:57-63

Brown SR, Daley RJ, McNeely RN (1977) Composition and stratigraphy of the fossil phorbin derivatives of Little
Round Lake, Ontario. Limnol Oceanogr 22:336-348

Buroker NF, Chanley P, Cranfield HJ, Dinami P (1983) Systematic status of two oyster populations of the genus Tiostrea from New Zealand and Chile. Mar Biol 77:191- 200

Calow P (1975) Defecation strategies of two freshwater gastropods, Ancylus fluviatilis Müll. and Planorbis contortus Linn. (Pulmonata) with a comparison of field and laboratory estimates of food absorption rate. Oecologia 20:51-63

Carriker MR, Gaffney PM, Elbe AF (1995) A catalogue of selected species of living oysters (Ostreacea) of the world. Chap 1. In: Elbe AF, Kennedy VS, Newell RIE (eds) The Eastern oyster Crassostrea virginica. Maryland Sea Grant College, University of Maryland System, College Park, MD

Chaparro OR, Thompson RJ (1998) Physiological energetics of brooding in Chilean oyster Ostrea chilensis. Mar Ecol Prog Ser 171:151-163

Chaparro OR, Thompson RJ, Ward JE (1993) In vivo observations of larval brooding in the Chilean oyster, Ostrea chilensis Philippi, 1845. Biol Bull 185:365-372

Chaparro, OR, Thompson, RJ, Emerson, CJ (1999) The velar ciliature in the brooded larva of the Chilean oyster Ostrea chilensis (Philippi, 1845). Biol Bull 197:104-111

DiSalvo LH, Alarcón E, Martínez E (1983) Induced spat production from Ostrea chilensis Philippi 1845 in mid-winter. Aquaculture 30:357-362

Gallardo CS (1989) Patrones de reproducción y ciclo vital en moluscos marinos bénticos. Una aproximación ecológico evolutiva. Medio Ambiente 10:25-35

Grahame J (1977) Reproductive effort and r-and K selection in two species of Lacuna (Gastropoda: Prosobranchia). Mar Biol 40:217-224

Harry HW (1985) Synopsis of the supraspecific clasification of living oysters (Bivalvia: Gryphaidae and Ostreidae). Veliger 28:121-158

Hawkins AJS, Bayne BL (1984) Seasonal variation in the balance between physiological mechanisms of feeding and digestion in Mytilus edulis (Bivalvia: Mollusca). Mar Biol 82:233-240

Hawkins AJS, Salkeld PN, Bayne BL, Gnaiger E, Lowe DM (1984) Feeding and resource allocation in Mytilus edulis: evidence for time averaged optimisation. Mar Ecol Prog Ser 20:273-287

Hawkins AJS, Navarro E, Iglesias IP (1990) Comparative allometries of gut-passage time, gut content and metabolic faecal loss in Mytilus edulis and Cerastoderma edule. Mar Biol 105:197-204

Kiørboe T, Møhlenberg F, Nicolajsen H (1982) Ingestion rate and gut clearance in Centropages hamatus (Lilljeborg) in relation to food concentration and temperature. Ophelia 21:181-194

Madin LP, Cetta CM (1984) The use of gut fluorescence to estimate grazing by oceanic salps. J Plankton Res 6:475-495

Mantoura RFC, Llewellyn CA (1983) The rapid determination of algal chorophyll and carotenoid pigments and their breakdown products in natural waters by reverse-phase high-performance liquid chromatography. Anal Chem Acta 151:297-314

Menge BA (1974) Effect of wave action and competition on brooding and reproductive effort in the sea star, Leptasterias hexactis. Ecology 55:84-93

Menge BA (1975) Brood or broadcast? The adaptative significance of different reproductive strategies in the two intertidal sea stars Leptasterias hexactis and Pisaster ochraceus. Mar Biol 31:84-93

Nelson JR (1989) Phytoplankton pigments in macrozooplankton feces: variability in carotenoid alterations. Mar Ecol Prog Ser 52:129-144 
Newell RI, Jordan SJ (1983) Preferential ingestion of organic material by the American oyster Crassostrea virginica. Mar Ecol Prog Ser 13:47-53

Penry DL, Frost BW (1990) Chl a degradation by Calanus pacificus: dependence on ingestion rate and digestive acclimation to food resources. Limnol Oceanogr 36:147-159

Purchon, RD (1977) The biology of Mollusca. Pergamon Press, London

Riemann, B (1978) Carotenoid interference in the spectrophotometric determination of clorophyll degradation products from natural populations of phytoplankton. Limnol Oceanogr 23:1059-1066

Schaffer WM (1974) Optimal reproductive effort in fluctuating environments. Am Nat 108:783-790

Silverman H, Steffens WL, Dietz TH (1985) Calcium from extracellular concentrations in the gills of freshwater unionid mussels is mobilized during reproduction. J Exp Zool 236:137-147

Silverman H, Kays WT, Dietz TH (1987) Maternal calcium contribution to glochidial shells in freshwater mussels (Eulamellibranchia-Unionidae). J Exp Zool 242:137-146

Sokal RR, Rohlf, FJ (1981) Biometry, 2nd edn. WH Freeman, New York

Solís I (1967) Observaciones biológicas en ostras (Ostrea chilensis Phillippi) de Pullinque. Biol Pesq 2:51-82

Sprung M (1984) Physiological energetics of mussel larvae (Mytilus edulis). IV. Efficiencies Mar Ecol Prog Ser 18:179-186

Strathmann RR (1978) The evolution and loss of feeding larval stages in marine invertebrates. Evolution 32:894-906

Strickland JB, Parsons TR (1972) A practical handbook of seawater analysis, 2nd edn. Bull Fish Res Board Can 167

Strom SL (1993) Production of pheopigments by marine protozoa: results of laboratory experiments analysed by HPLC. Deep-Sea Res 409:57-80

Taghon GL (1981) Beyond selection: optimal ingestion rate as a function of food value. Am Nat 118:202-214

Tankersley RA (1992) Larval brooding by the freshwater unionid mussel Anodonta cataracta and its effect on filtration, ventilation, and respiration. PhD thesis, Wake Forest University, Winston-Salem, NC

Tankersley RA, Dimock RV (1993) The effect of larval brooding on the filtration rate and particle retention efficiency of Pyganodon cataracta (Bivalvia: Unionidae). Can J Zool 71: 1934-1944

Thompson RJ, Bayne BL (1972) Active metabolism associated with feeding in the mussel Mytilus edulis. J Exp Mar Biol

Editorial responsibility: Roger Hughes (Contributing Editor), Bangor, Wales, UK
Ecol 8:191-212

Todd CD (1979) Reproductive energetics of two species of dorid nudibranchs with planktotrophic and lecithotrophic larval strategies. Mar Biol 53:57-68

Toro JE, Winter JE (1983) Estudios en la ostricultura Quempillén, un estuario del sur de Chile. Parte I. La determinación de los factores abióticos en la cuantificación del seston como oferta alimenticia y su utilización por Ostrea chilensis. Mems Asoc Latinoam Acuicult 5:129-143

Toro JE, Chaparro OR (1990) Conocimiento biológico de Ostrea chilensis (Philippi, 1845). Impacto y perspectivas de la ostricultura en Chile. In: Hernández A (ed) Cultivo de moluscos en América Latina. CIID, Canadá Bogotá, p 231-264

Urban JL, McKenzie CH, Deibel D (1992) Seasonal differences in the content of Oikopleura vanhoeffeni and Calanus finmarchicus faecal pellets: illustrations of zooplankton food web shifts in coastal Newfoundland waters. Mar Ecol Prog Ser 84:255-264

Van Weel PB (1961) The comparative physiology of digestion in molluscs. Am Zool 1:245-252

Vernet M, Lorenzen CJ (1987) The relative abundance of pheophorbide $a$ and pheophytin $a$ in temperate marine waters. Limnol Oceanogr 32:352-358

Waller TD (1981) Functional morphology and development of veliger larvae of the European oyster, Ostrea edulis Linné. Smithson Contrib Zool 328:1-70

Widdows J, Fieth P, Worrall CM (1979) Relationship between seston available, food and feeding activity in the common mussel Mytilus edulis. Mar Biol 50:195-207

Williams GC (1966) Natural selection. The costs of reproduction. Am Nat 100:687-690

Winter JE, Gallardo C, Araya J, Toro J, Gleisner A (1983) Estudios en la ostricultura Quempillén, un estuario del sur de Chile. Parte II. La influencia de los factores ambientales sobre el crecimiento y los períodos de reproducción en Ostrea chilensis. Mems Asoc Latinoam Acuicult 5:145-159

Wright SW, Jeffrey SW, Mantoura RFC, Llewellyn CA, Bjornland T, Repeta D, Welshmeyer N (1991) Improved HPLC method for the analysis of chlorophylls and carotenoids from marine phytoplankton. Mar Ecol Prog Ser 77: 183-196

Yentsch CS (1967) The measurement of chloroplastic pigments - thirty years of progress. In: Golterman HC, Clymo RS (eds) Chemical environment in the aquatic habitat. North-Holland, Amsterdam, p 225-270

Submitted: February 16, 2000; Accepted: January 23, 2001 Proofs received from author(s): October 16, 2001 